\title{
Characteristic Morphology and Genetic Variability of Benggala Grass (Panicum maximum cv Purple guinea) through Gamma Ray Irradiated on Acid Land
}

\author{
Fanindi $\mathrm{A}^{1}$, Sutjahjo $\mathrm{SH}^{2}$, Aisyah $\mathrm{SI}^{2}$, Purwantari $\mathrm{ND}^{1}$ \\ ${ }^{1}$ Indonesian Research Institute for Animal Production, PO Box 221, Bogor - Indonesia \\ ${ }^{2}$ Bogor Agricultural University \\ E-mail:afanindi@gmail.com
}

(received 21-08-2016; revised 17-11-2016; accepted 23-11-2016)

\begin{abstract}
ABSTRAK
Fanindi A, Sutjahjo SH, Aisyah SI, Purwantari ND. 2016. Karakter morfologi dan keragaman genetis rumput Benggala (Panicum maximum cv Purple guinea) melalui iradiasi sinar gamma pada lahan masam. JITV 21(4): 205-214. DOI: http://dx.doi.org/10.14334/jitv.v21i4.1635

Mutasi induksi menggunakan sinar gamma adalah salah satu cara untuk meningkatkan keragaman rumput Benggala (Panicum maximum). Keragaman merupakan modal utama dalam melakukan seleksi untuk menghasilkan varietas rumput Benggala pada lahan masam. Penelitian bertujuan untuk mengetahui karakter morfologi dan keragaman genetik rumput Benggala yang mendapat perlakuan sinar gamma. Penelitian dilakukan di lahan masam yaitu di daerah Tenjo Kab. Bogor yang memiliki pH 4,9-5,5 dan kandungan Al-dd 2,26 cmol/kg dengan kejenuhan Al 10,68\%. Penelitian dimulai dengan mencari radio sensitivitas rumput Benggala, selanjutnya dari radio sensitivitas tersebut ditentukan dosis perlakuan radiasi yaitu $200 \mathrm{~Gy}, 250$ Gy, 300 Gy dan 350 Gy. Perlakuan dosis radiasi dilakukan secara acute dan fractionated, sehingga terdapat 8 dosis perlakuan ditambah kontrol (tanaman tanpa di radiasi). Pengamatan variabel yang diukur adalah tinggi tanaman, tinggi batang, diameter batang, panjang ruas, panjang daun, leber daun, bobot segar, bobot kering dan jumlah anakan. Hasil penelitian menunjukkan bahwa radio sensitivitas rumput Benggala yang dihasilkan berupa letahal doses (LD) LD 20 dan LD50 yaitu 176,83 Gy dan 358,23 Gy. Dengan persamaan matematikanya: $\mathrm{Y}=44,22+45,91 \mathrm{X} \operatorname{Cos}(0.0042 \mathrm{x}-0.07)$. Karakter morfologi pada M1 menunjukkan bahwa dosis radiasi mempengaruhi semua variabel karakter tanaman. Dosis 300 Gy fractionated (150 Gy x 2) menghasilkan bobot segar tanaman yang lebih tinggi. Sementara itu, pada generasi M1V1 dosis radiasi yang memberikan bobot segar hijauan tinggi adalah dosis $250 \mathrm{~Gy}$. Heritabilitas sedang sampai tinggi dengan nilai koefisien keragaman genetik (KKG) cukup tinggi sampai tinggi diperoleh pada karakter jumlah anakan, bobot segar dan bobot kering. Sehingga memungkinkan untuk dilakukan seleksi selanjutnya pada ketiga karakter ini.
\end{abstract}

Kata Kunci: Panicum maximum, Iradiasi, Mutasi, Morfologi, Keragaman Genetis

\section{ABSTRACT}

Fanindi A, Sutjahjo SH, Aisyah SI, Purwantari ND. 2016. Characteristic morphology and genetic variability of Benggala grass (Panicum maximum cv Purple guinea) through gamma ray irradiated on acid land. JITV 21(4): 205-214. DOI: http://dx.doi.org/10.14334/jitv.v21i4.1635

The induction mutation using gamma rays is one way to increase the diversity of Benggala grass (Panicum maximum). Diversity is the main base in selection to produce varieties of Benggala grass on acid land. The aim of this study is to know the morphological character and genetic diversity of grass that received gamma rays. The research was conducted in Tenjo district, Bogor which has $\mathrm{pH} 4.9-5.5$ and the content of Al-dd $2.26 \mathrm{cmol} / \mathrm{kg}$ with Al saturation of $10.68 \%$. The study was started by identifying for Benggala grass radio sensitivity, then from radio sensitivity determined radiation treatment dose was decided of: $200 \mathrm{~Gy}, 250 \mathrm{~Gy}, 300 \mathrm{~Gy}$ and $350 \mathrm{~Gy}$. Treatment of radiation dose is acute and fractionated, so there are 8 treatment doses plus control (plants without radiation). The variables measured were plant height, stem height, stem diameter, length of segment, leaf length, leaf width, fresh weight, dry weight, and number of tillers. Results showed that the radio sensitivity of Benggala grass produced in the form of lethal doses (LD) LD 20 and LD50 was $176.83 \mathrm{~Gy}$ and $358.23 \mathrm{~Gy}$. By the mathematical equation: $\mathrm{Y}=44.22+45.91 \mathrm{X} \operatorname{Cos}(0.0042 \mathrm{x}-0.07)$. The morphological character of M1 shows that the radiation dose affected the measured variable. $300 \mathrm{~Gy}$ fractionated radiation dose (150 Gy x 2) resulted in higher fresh weight of the plant. While in the generation of M1V1 radiation dose of $250 \mathrm{~Gy}$ produced high fresh forage weight. Medium to high heritability with GVC value (criteria of coefficient of genetic variability) is high enough until high is obtained on the character of the number of tillers, fresh weight and dry weight. So it is possible to do next selection on these three characters.

Key Words: Panicum maximum, Irradiation, Mutation, Morfology, Genetic Variability 


\section{INTRODUCTION}

Benggala grass is one of grasses widely used by farmer in Indonesia. The grass has production by $6.7-15$ ton of DM/ha/year (Hare et al. 2009). The grass is easily harvested, may grow back after pruning, requires few pesticides and non intensive cultivation management. It is also resistant to dry land and grows well on various soil types, even tolerant to moderate shading which means it may grow under tree shade or bush. These are how the Benggala grass is potential for "ideal" forage as fiber source for ethanol production besides its low management cost and abundant production (Ratsamee et al. 2012). It also may be used as quality "cut and carry" grass for beef and dairy cattle (Aganga \& Tshwenyane 2004; Nakamanee et al. 2008) and also grass for pasture with good quality (Carnevalli et al. 2006).

One of constrains of the Benggala grass cultivation is various tolerance to the acid land. A research result showed that the Benggala grass did not grow well on both oxisol and ultisol lands (Chen \& Hutton 1992), while Almeida et al. (2000) reported that the most genotype of Benggala grass had low tolerance to the acid land (aluminum stress). All this time, in Indonesia, the approach for cultivation improvement was through fertilization or addition of lime, where the breeding approach to create Benggala grass varieties tolerant to acid land has not been conducted. Even though, the use of Benggala grass varieties tolerant to the suboptimal land may save production cost by 1 million/ha (Karti 2016). The forming of varieties tolerant to acid land through mutation may be performed by induction mutation using gamma ray radiation. The induction mutation on Benggala grass is expected to increase mutation frequency to increase its diversity. All this time, the diversity of Benggala grass in Indonesia is remain low since there is no breeding program besides its apomixis reproduction generating similar offspring to the parent plant.

The success of induction mutation using the gamma ray radiation on the plant has successfully created plant varieties tolerant to sub optimal land such as in soybean (Hanafiah et al. 2010), rice (Sobrizal 2016) and wheat (Nur et al. 2014). Many researches of the induction mutation on Benggala grass have been reported, such as quality improvement through tissue and protoplasm isolations (Akashi \& Adachi 1991) and development of tolerance on acid land (Pongtongkam et al. 2005). The use of induction mutation on many plants, including the Benggala grass showed that the induction mutation using gamma ray radiation may be conducted to create Benggala grass cultivar tolerant to acid land. The forming of Benggala grass tolerant to acid land requires several steps, where the early stage is to determine radio-sensitivity and observation of morphology of generation M1 and M1V1. Therefore, this study was conducted to determine $\mathrm{LD}_{50}$, observing morphology characteristics of Benggala grass irradiated using gamma ray to obtain mutative mutants tolerant to the acid land.

\section{MATERIALS AND METHODS}

\section{Determination of radio-sensitivity of Benggala grass}

Radio-sensitivity of Benggala grass is determined by irradiation using gamma ray from 0 doses (control) to $1000 \mathrm{~Gy}$. The irradiation was performed at National Nuclear Energy Agency of Indonesia. Benggala grass seed used was cv Purple guinea. The seedling was radiated by gamma ray doses by $0 \mathrm{~Gy}, 50 \mathrm{~Gy}, 100 \mathrm{~Gy}$, 150 Gy, 200 Gy, 250 Gy, 300 Gy, 350 Gy, 400 Gy, 450 Gy, 500 Gy, 550 Gy, 600 Gy, 650 Gy, 700 Gy, 750 Gy, 800 Gy, 850 Gy, 900 Gy, 950 Gy and 1000 Gy. The gamma ray source was Cobalt 60 delivered through irradiator gamma chamber 4000A. The number of seedling irradiated per doses was 500 seeds. Then, the seeds were planted into germination tub and were evaluated on the percentage of growth rate at three weeks after planting. Variables observed in this study were percentage of growth rate (1), the amount of leave (2), seedling height which measured from root to peak (3). The percentage data were used in determining the Lethal Dose 50 value $\left(\mathrm{LD}_{50}\right)$ analyzed using the Curvefit Analysis program.

\section{Identification of putative mutants of Benggala grass (M1) and the diversity of agronomy characteristics of M1V1 generation}

The field study was conducted at Regional Technical Implementing Unit of dry land, District of Tenjo, Bogor Regency for 10 months. The research land has $\mathrm{pH}$ by $4.9-5.5$ and Al-dd content by 2.26-4.52 $\mathrm{cmol} / \mathrm{kg}$ with the Al saturation by $10.68 \%$. This study was designed in Randomized Block Design (RBD) with three replications. The treatment performed in this study was radiation doses between the $\mathrm{LD}_{20}-\mathrm{LD}_{50}$ consisted of four acute doses and four fractionated doses, and the control. The doses used were $200 \mathrm{~Gy}, 250 \mathrm{~Gy}, 300 \mathrm{~Gy}$, 350 Gy and 100 × 2 Gy, 125 x 2 Gy, 150 x 2 Gy and $175 \times 2$ Gy and the control. The irradiation was conducted at the National Nuclear Energy Agency of Indonesia of Pasar Jumat-Jakarta. The irradiated Benggala grass seed was 200 seeds each dose grew in polybag (one seed each), then transferred into the field after one month.

The observation of morphology characteristics of the M1V1 was conducted at the same location as the characteristic observation of M1. The crops material used was all crops in M1. A total of 2-3 seedlings were 
collected from each individual of M1 to become M1V1. The number of crops would be planted in the M1V1 were around 2,700-3,000 plants. The maintenance and cultivation were similarly performed as in the M1.

The board-sense heritability value was counted following the Kalton et al. (1952) formula:

$$
h^{2}=\quad \frac{\sigma^{2} S 1-\sigma^{2} S 0}{\sigma^{2} S 1}
$$

Where:

$\sigma^{2} \mathrm{~S} 0=\sigma^{2} \mathrm{c}=$ The variance between the seedling;

$\sigma^{2} \mathrm{~S} 1=$ The derivative variance of the self clone or the seedling mutation result

The diversity was counted by:

$$
\sigma^{2}=\frac{\sum_{i=1}^{n}\left(X_{i}-\bar{X}\right)^{2}}{n}
$$

Where:

$$
\begin{aligned}
\sigma^{2} & =\text { Variance; } \\
x_{i} & =\text { Midpoint; } \\
x^{-} & =\text {Average; } \\
n & =\text { The number of data }
\end{aligned}
$$

Genetic variability was determined by the basis of genetic variability coefficient (GVC) using the following method by Singh \& Chaudhari (1977):

$$
K K G=\left(\sqrt{\sigma_{g}^{2} / x}\right) x 100
$$

\section{RESULTS AND DISCUSSION}

\section{Radio-sensitivity of Benggala grass}

Observation of radio-sensitivity in this study was conducted by observing the $\mathrm{LD}_{50}$ of the irradiated Benggala grass. The observation result was presented in Table 1. The data then were counted and analyzed using Curve-fit and then its mathematic formula was formed. The Curve-fit analysis result (Figure 1) showed that the $\mathrm{LD}_{50}$ and $\mathrm{LD}_{20}$ value of Benggala grass using the seed were 358.23 Gy and 176.83 Gy respectively. While, its mathematic formula was Model Sinusoidal Fit: $Y=44.22+45.91 \times \operatorname{Cos}(\mathbf{0 . 0 0 4 2} \times-\mathbf{0 . 0 7})$. The $L_{50}$ value may also be determined using crop height indication. The height will decrease along with the increase of radiation. The crop height at the 250-350 Gy decreased a half compared to the control. This shows that the crop height may be an indicator to determine the $\mathrm{LD}_{50}$ of Benggala grass irradiated by gamma ray. The research of use of the crop height and root length has been performed by Ambavane et al. (2015) to measure $\mathrm{LD}_{50}$ of millet plant.

The sensitivity rate may be observed from the response of crops both of the morphology, sterility or lethal doses $50\left(\mathrm{LD}_{50}\right)$. The lethal doses $50 \mathrm{LD}_{50}$ is a dose causing the death of $50 \%$ irradiated population. From the mutation study done, commonly, the desirable mutation is around the $\mathrm{LD}_{50}$ or slightly under $\mathrm{LD}_{50}$. And commonly, in this range, it is obtained high

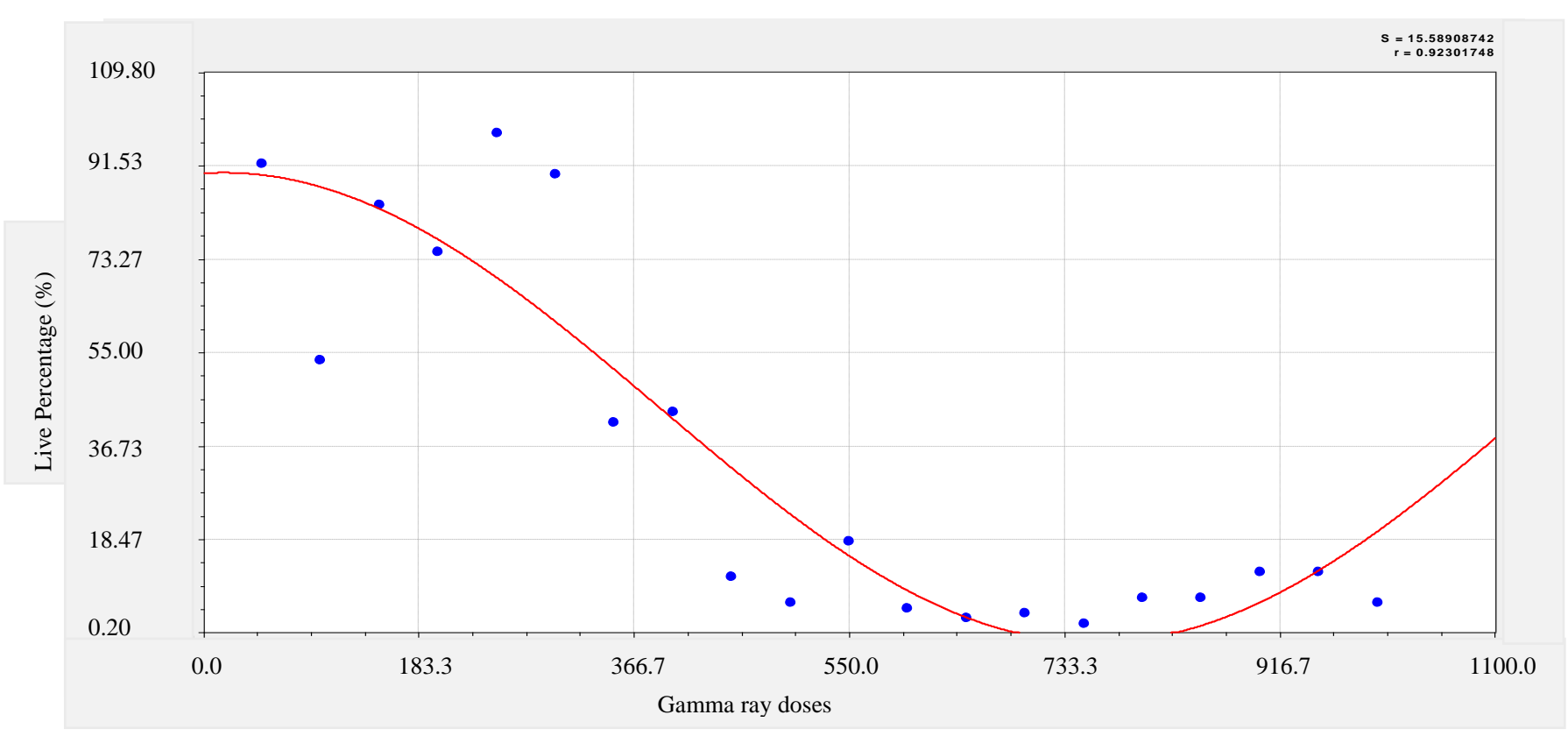

Figure 1. Graphic of lethal doses by $20-50 \%$ of Benggala grass irradiated by gamma ray by $0-1000 \mathrm{~Gy}$. 
Table 1. Live rate percentage, sprout height and the number of leave of Benggala grass at one month after planting

\begin{tabular}{|c|c|c|c|}
\hline Doses (Gy) & Crop height $(\mathrm{cm})$ & The number of leaves & Live rate percentage $(\%)$ \\
\hline 0 & $9.01 \pm 3.00$ & $3.33 \pm 0.97$ & 100.00 \\
\hline 50 & $9.48 \pm 3.00$ & $3.44 \pm 0.67$ & 91.92 \\
\hline 100 & $7.36 \pm 3.11$ & $3.43 \pm 0.89$ & 53.54 \\
\hline 150 & $6.93 \pm 2.76$ & $3.51 \pm 0.95$ & 83.84 \\
\hline 200 & $4.66 \pm 2.36$ & $2.95 \pm 1.23$ & 74.75 \\
\hline 250 & $4.24 \pm 2.56$ & $2.76 \pm 1.23$ & 97.98 \\
\hline 300 & $4.83 \pm 2.83$ & $2.91 \pm 1.23$ & 89.90 \\
\hline 350 & $3.28 \pm 2.09$ & $2.27 \pm 1.48$ & 41.41 \\
\hline 400 & $3.04 \pm 1.92$ & $2.14 \pm 1.54$ & 43.43 \\
\hline 450 & $1.76 \pm 1.17$ & $1.18 \pm 1.60$ & 11.11 \\
\hline 500 & $1.17 \pm 0.40$ & $0.83 \pm 0.41$ & 6.06 \\
\hline 550 & $0.86 \pm 0.56$ & $0.44 \pm 0.51$ & 18.18 \\
\hline 600 & $1.22 \pm 0.75$ & $0.40 \pm 0.89$ & 5.05 \\
\hline 650 & $0.67 \pm 0.47$ & $1.00 \pm 1.73$ & 3.03 \\
\hline 700 & $0.65 \pm 0.47$ & $0.50 \pm 1.00$ & 4.04 \\
\hline 750 & $0.30 \pm 0.14$ & $0.00 \pm 0.00$ & 2.02 \\
\hline 800 & $0.39 \pm 0.18$ & $0.00 \pm 0.00$ & 7.07 \\
\hline 850 & $0.63 \pm 0.42$ & $0.29 \pm 0.49$ & 7.07 \\
\hline 900 & $0.33 \pm 0.09$ & $0.00 \pm 0.00$ & 12.12 \\
\hline 950 & $0.29 \pm 0.12$ & $0.00 \pm 0.00$ & 12.12 \\
\hline 1000 & $0.22 \pm 0.04$ & $0.00 \pm 0.00$ & 6.06 \\
\hline
\end{tabular}

diversity (Aisyah 2009). The $\mathrm{LD}_{50}$ is also obtained from the breeders to induce the mutation, where it is expected a balanced physiologies damage with the obtained genetic change (Sudrajat \& Zanzibar 2009). The $\mathrm{LD}_{50}$ range doses may be used to both determine sensitivity rate against physical and chemical mutagens and estimate the appropriate dose or concentration to induce the mutation (Abdullah et al. 2009).

\section{Morphology characteristic of M1 of Benggala grass at the acid land}

The research result of the M1 is presented in Table 2. It shows that dose of gamma ray radiation affects leaves height and width. The highest crop was in the $150 \times 2$ Gy doses (300 Gy with divided doses) by 56.11 $\mathrm{cm}$, while the lowest crop was in the 350 Gy by 37.65 $\mathrm{cm}$. This shows that higher radiation dose will decrease the crops height. This is in accordance with the research performed by induction mutation of gamma ray radiation, where the addition of the gamma ray will prevent the growth as in the millet (Ambavane 2015) and soybean (Hanafiah 2012).

The leaves width was affected by dose of gamma ray radiation. The widest leaves was in the $150 \times 2 \mathrm{~Gy}$, while the lowest doses was in radiation of $300 \mathrm{~Gy}, 350$ Gy and 175 x 2 Gy which was the highest doses in this study. This also shows that the increase of gamma ray doses will prevent the crop growth including the height of crops and the leaves width.

The fresh crop weight, dry crop weight and the number of seedling was presented in Table 3 . The heaviest fresh crop weight was in the $150 \times 2$ Gy by $47.61 \mathrm{~g} / \mathrm{crop}$. The fresh crop weight at the $150 \mathrm{x} 2 \mathrm{~Gy}$ dose was also higher compared to the control. While, the lowest fresh crop weight was at $300 \mathrm{~Gy}$ and $350 \mathrm{~Gy}$ by $9.93 \mathrm{gr} / \mathrm{crop}$ and $13.18 \mathrm{gr} / \mathrm{crop}$, respectively. The effect of radiation doses that leads to better productivity performance of crops at the sub-optimal land was also 
Fanindi et al. Characteristic morphology and genetic variability of Benggala grass (Panicum maximum cv Purple guinea)

Table 2. Average crop height, leaves width and leave length of Benggala grass (M1) irradiated by gamma ray for three months at the acid land

\begin{tabular}{lccc}
\hline \hline \multirow{2}{*}{ Dose of gamma ray $(\mathrm{Gy})$} & \multicolumn{3}{c}{ Variable } \\
\cline { 2 - 4 } & Crop height $(\mathrm{cm})$ & Leave width $(\mathrm{cm})$ & Leave length $(\mathrm{cm})$ \\
\hline Control & $45.61^{\mathrm{ab}}$ & $1.00^{\mathrm{ab}}$ & $30.71^{\mathrm{a}}$ \\
200 & $46.02^{\mathrm{ab}}$ & $0.97^{\mathrm{ab}}$ & $29.54^{\mathrm{a}}$ \\
250 & $44.84^{\mathrm{ab}}$ & $0.95^{\mathrm{ab}}$ & $29.46^{\mathrm{a}}$ \\
300 & $38.64^{\mathrm{b}}$ & $0.86^{\mathrm{b}}$ & $29.33^{\mathrm{a}}$ \\
350 & $37.65^{\mathrm{b}}$ & $0.85^{\mathrm{b}}$ & $26.04^{\mathrm{a}}$ \\
$100 \times 2$ & $45.55^{\mathrm{ab}}$ & $1.00^{\mathrm{ab}}$ & $30.53^{\mathrm{a}}$ \\
$125 \times 2$ & $45.20^{\mathrm{ab}}$ & $1.03^{\mathrm{ab}}$ & $29.86^{\mathrm{a}}$ \\
$150 \times 2$ & $56.11^{\mathrm{a}}$ & $1.17^{\mathrm{a}}$ & $34.41^{\mathrm{a}}$ \\
$175 \times 2$ & $40.18^{\mathrm{b}}$ & $0.85^{\mathrm{b}}$ & $25.83^{\mathrm{a}}$ \\
\hline
\end{tabular}

${ }^{a}$ The same numbers in the same column followed by same word means no significant difference at test degree of $5 \%$ (Duncan multiple range test).

Table 3. Average fresh crop weight, dry crop weight and the number of tiller of Benggala grass (M1) irradiated by gamma ray for three months at the acid land

\begin{tabular}{lccc}
\hline \hline \multirow{2}{*}{ Dose of gamma ray $(\mathrm{Gy})$} & \multicolumn{3}{c}{ Variable } \\
\cline { 2 - 4 } Control & Fresh weight $(\mathrm{g})$ & Dry weight $(\mathrm{g})$ & The number of tiller (crop) \\
200 & $26.47^{\mathrm{ab}}$ & $9.17^{\mathrm{ab}}$ & $13.91^{\mathrm{bc}}$ \\
250 & $20.00^{\mathrm{b}}$ & $7.34^{\mathrm{b}}$ & $14.67^{\mathrm{bc}}$ \\
300 & $26.23^{\mathrm{ab}}$ & $8.79^{\mathrm{b}}$ & $17.80^{\mathrm{ab}}$ \\
350 & $9.93^{\mathrm{b}}$ & $4.14^{\mathrm{b}}$ & $11.85^{\mathrm{c}}$ \\
$100 \times 2$ & $13.18^{\mathrm{b}}$ & $5.37^{\mathrm{b}}$ & $17.08^{\mathrm{ab}}$ \\
$125 \times 2$ & $25.26^{\mathrm{b}}$ & $8.72^{\mathrm{b}}$ & $14.70^{\mathrm{bc}}$ \\
$150 \times 2$ & $23.06^{\mathrm{b}}$ & $8.73^{\mathrm{b}}$ & $15.29^{\mathrm{bc}}$ \\
$175 \times 2$ & $47.61^{\mathrm{a}}$ & $16.00^{\mathrm{a}}$ & $20.81^{\mathrm{a}}$ \\
\hline
\end{tabular}

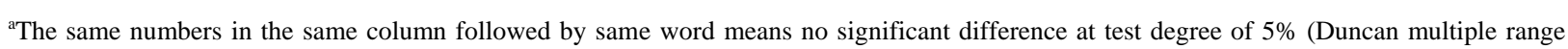
test)

reported in the soybean in the dry land (Hanafiah 2012); high temperature wheat (Setiawan 2015); soybean at the dry acidic land (Giono et al. 2014) and corn at the acid land (Lubis et al. 2014), whereas, the induction mutation in the Benggala grass resulted in a mutant tolerant to acid land (Pongtokam et al. 2005). The influence of the induction mutation (gamma ray) to the fresh weight is allegedly due to a mutation at the gen level causing a change in structure and position of gen in the chromosome. This leads to phenotype change of an organism. The change of the number of basic chromosome both when the increase or decrease of one set or part of chromosome causing the appearance or the disappearance of one character. After the established mutation in the gen or chromosome level in a population, it is followed by nature or Artificial selection (Ambavane et al. 2015).

This research result also showed that dry crop weight was influenced by gamma ray, where the heaviest dry crop production was at $150 \mathrm{~Gy}$ x 2 (300 Gy fractionated) by $16.00 \mathrm{gr} / \mathrm{crop}$. The heavy dry weight of crop at the 150 Gy $\times 2$ was in accordance with the heavy fresh crop weight at the $150 \mathrm{~Gy} \times 2$. It is also related to the high number of seedling in those doses. The highest number of seedling in this study was at the 
150 Gy x 2 by 20.81 seedlings. This number was higher compared to the other doses, even than the control.

\section{Morphology characteristic of M1V1 in the acid land}

The crop height, leaves width and leaves length of M1V1 crop in the acid land was presented in Table 4. The highest crop was at the $250 \mathrm{~Gy}$, while the lowest one was at the 125 Gy x 2 (250 Gy fractionated). The leaves width did not show a difference between the treatments. The longest leave was at $200 \mathrm{~Gy}$ and control, while the shortest one was at the 175 Gy x 2 . The decrease of characteristic along with the increase of doses of gamma ray radiation, commonly occurred in the crops experiencing gamma ray radiation, as in the soybean crop (Hanafiah 2010) and paddy (Sobrizal 2016).

The fresh crop weight, dry crop weight and the number of seedling were presented in Table 5. The heaviest fresh weight was at $250 \mathrm{~Gy}$ and control, while the lightest fresh crop weight was at 125 Gy x 2 (250 fractionated). The heaviest dry crop weight was also at $250 \mathrm{~Gy}$. While highest number of seedling was at 200 Gy and the lowest one was at the $125 \times 2$ Gy.

The stem diameter, stem height and segment length was presented in Table 6 . The segment length and stem height did not show a difference between the treatments. The widest stem diameter was at $350 \mathrm{~Gy}$ by $5.23 \mathrm{~cm}$, while the shortest one was in the $125 \mathrm{~Gy} \times 2$.

Table 4. Average crop height, leaves width and leaves length of Benggala grass (M1V1) irradiated by gamma ray for three months at the acid land

\begin{tabular}{lccc}
\hline \hline \multirow{2}{*}{ Dose of gamma ray $(G y)$} & \multicolumn{3}{c}{ Variable } \\
\cline { 2 - 3 } & Crop height $(\mathrm{cm})$ & Leaves width $(\mathrm{cm})$ & Leaves length $(\mathrm{cm})$ \\
\hline Control & $133.84^{\mathrm{a}}$ & $2.13^{\mathrm{a}}$ & $57.62^{\mathrm{a}}$ \\
200 & $128.37^{\mathrm{ab}}$ & $1.97^{\mathrm{a}}$ & $57.43^{\mathrm{a}}$ \\
250 & $136.77^{\mathrm{a}}$ & $2.06^{\mathrm{a}}$ & $54.41^{\mathrm{ab}}$ \\
300 & $123.80^{\mathrm{ab}}$ & $1.86^{\mathrm{a}}$ & $54.58^{\mathrm{ab}}$ \\
350 & $127.90^{\mathrm{ab}}$ & $1.99^{\mathrm{a}}$ & $54.80^{\mathrm{ab}}$ \\
$100 \mathrm{x} 2$ & $125.47^{\mathrm{ab}}$ & $2.00^{\mathrm{a}}$ & $54.96^{\mathrm{ab}}$ \\
$125 \mathrm{x} 2$ & $110.84^{\mathrm{b}}$ & $1.57^{\mathrm{a}}$ & $53.05^{\mathrm{b}}$ \\
$150 \mathrm{x} 2$ & $127.99^{\mathrm{ab}}$ & $1.80^{\mathrm{a}}$ & $52.83^{\mathrm{b}}$ \\
$175 \times 2$ & $117.86^{\mathrm{ab}}$ & $2.08^{\mathrm{a}}$ & $52.99^{\mathrm{b}}$ \\
\hline
\end{tabular}

${ }^{a}$ The same numbers in the same column followed by same word means no significant difference at test degree of 5\% (Duncan multiple range test).

Table 5. Average fresh crop weight, dry crop weight and the number of seedling of Benggala grass (M1V1) irradiated by gamma ray for three months at the acid land

\begin{tabular}{lccc}
\hline \hline \multirow{2}{*}{ Dose of gamma ray (Gy) } & \multicolumn{3}{c}{ Variable } \\
\cline { 2 - 4 } & Fresh weight $(\mathrm{g} / \mathrm{crop})$ & Dry weight $(\mathrm{g} / \mathrm{crop})$ & The number of seedling (crop) \\
\hline Control & $346.92^{\mathrm{a}}$ & $84.77^{\mathrm{ab}}$ & $14.64^{\mathrm{ab}}$ \\
200 & $313.91^{\mathrm{abc}}$ & $77.43^{\mathrm{ab}}$ & $15.47^{\mathrm{a}}$ \\
250 & $350.97^{\mathrm{a}}$ & $87.48^{\mathrm{a}}$ & $14.84^{\mathrm{ab}}$ \\
300 & $306.85^{\mathrm{abc}}$ & $77.87^{\mathrm{ab}}$ & $12.90^{\mathrm{b}}$ \\
350 & $313.98^{\mathrm{ab}}$ & $83.19^{\mathrm{ab}}$ & $14.39^{\mathrm{ab}}$ \\
$100 \times 2$ & $327.46^{\mathrm{ab}}$ & $80.63^{\mathrm{ab}}$ & $13.74^{\mathrm{ab}}$ \\
$125 \times 2$ & $215.17^{\mathrm{c}}$ & $61.56^{\mathrm{b}}$ & $12.79^{\mathrm{b}}$ \\
$150 \times 2$ & $319.43^{\mathrm{ab}}$ & $86.70^{\mathrm{ab}}$ & $14.09^{\mathrm{ab}}$ \\
$175 \times 2$ & $241.34^{\mathrm{bc}}$ & $65.79^{\mathrm{ab}}$ & $13.43^{\mathrm{ab}}$ \\
\hline
\end{tabular}

${ }^{a}$ The same numbers in the same column followed by same word means no significant difference at test degree of $5 \%$ (Duncan multiple range test). 


\section{Genetic variability and heritability of M1V1 in the acid land}

The heritability and genetic variability of M1V1 in the acid land was presented in Table 7 and 8 . The genetic diversity and heritability are used to estimate genetic development from selection of Barmawi et al. (2013). The genetic diversity itself is very difficult to study characteristic, therefore other genetic parameters such as heritability is required (Satoto \& Suprihatno 1996). Heritability is genetic parameter used to assess the ability of a genotype in a crop population in inheriting their characteristics or estimation to assess how much the diversity of appearance of a genotype in a population, especially caused by genetic factors. The heritability of a characteristic is highly required to be assessed to determine the efficiency of a selection (Seyoum et al. 2012). High heritability value shows that genetic factor is more involved in determining those characteristics compared to the influence of environment, so that a selection on the characteristics is very possible.

The heritability and genetic variability value of Benggala grass for the crop height, stem height, segment length, leave length and leaves width at the acid land were presented in Table 7. The GVC value was counted from the basis of relative GVC from its absolute value where the absolute value of GVC in this study was $0-56.41 \%$ (Table 7 and 8 ). The value $56.41 \%$ was used as $100 \%$ relative value. The relative criteria values of the GVC were low (0-25\%), medium (25$50 \%)$, quite high $(50-75 \%)$ and high (75-100\%) (Moedjiono \& Mejaya 1994). It means that the absolute values in this study were $0 \%<\mathrm{x} \leq 14.10 \% ; 14.10 \%<\mathrm{x}$ $\leq 28.21 \% ; 28.21 \%<\mathrm{x} \leq 42.31 \%$; and $42.31 \%<\mathrm{x}$ $\leq 56.41 \%$.

The crop height, stem height, stem diameter and segment length had low to moderate heritability. The moderate heritability of crop height was at 100 Gy x 2 , 300 Gy and 150 Gy x 2. The heritability of stem height was at $100 \times 2 \mathrm{~Gy}$, as well as the stem diameter, the moderate heritability value was at $100 \mathrm{~Gy}$ x 2, $150 \mathrm{~Gy}$ x 2 , whereas the segment length had moderate heritability value at $300 \mathrm{~Gy}, 100 \mathrm{~Gy}$ x 2 and 150 Gy x 2. Narrow heritability value of crop height, leaves width and leaves length in the M2 generation is also reported by Poerba (2004) of Talinum paniculatum Jacq. (Gaertn).

Heritability value of leaves length had narrow to moderate value, where the moderate heritability was at 100 Gy x 2 dan 350 Gy. The genetic variability of leaves length low value. Heritability value of leaves width had high to low value range, where the high heritability value was at 300 Gy. Diversity of this characteristic was from low to rather low.

The number of seedling had moderate to high value, where the high value was at $250 \mathrm{~Gy}$ and $150 \mathrm{~Gy} \times 2$. The genetic diversity value of the number of seedling of Benggala grass was in medium to quite high value range. The high heritability value and quite high diversity is allowed it to do further selection on the number of seedling variable.

The fresh and dry crop weights are two indicators in determining forage production. The heritability of fresh crop weight (Table 8) was in narrow to high value range. Average dose had moderate heritability value. High heritability of fresh crop weight was at 100 Gy x 2 with high variability genetic which means a possibility to do selection in this characteristic. Dry crop weight had medium to quite high heritability value range.

Table 6. Stem diameter, stem height, and segment length of Benggala grass (M1V1) irradiated by gamma ray for 3 months in the acid land

\begin{tabular}{lccc}
\hline \hline \multirow{2}{*}{ Dose of gamma ray $(\mathrm{Gy})$} & \multicolumn{3}{c}{ Variable } \\
\cline { 2 - 4 } & Stem diameter $(\mathrm{cm})$ & Stem height $(\mathrm{cm})$ & Segment length $(\mathrm{cm})$ \\
\hline Control & $4.89^{\mathrm{ab}}$ & $76.56^{\mathrm{a}}$ & $19.01^{\mathrm{a}}$ \\
200 & $5.15^{\mathrm{ab}}$ & $73.28^{\mathrm{a}}$ & $19.20^{\mathrm{a}}$ \\
250 & $4.93^{\mathrm{ab}}$ & $82.25^{\mathrm{a}}$ & $19.16^{\mathrm{a}}$ \\
300 & $5.17^{\mathrm{ab}}$ & $72.53^{\mathrm{a}}$ & $19.11^{\mathrm{a}}$ \\
350 & $5.23^{\mathrm{a}}$ & $77.01^{\mathrm{a}}$ & $19.17^{\mathrm{a}}$ \\
$100 \mathrm{x} 2$ & $5.09^{\mathrm{ab}}$ & $78.83^{\mathrm{a}}$ & $19.14^{\mathrm{a}}$ \\
$125 \times 2$ & $4.85^{\mathrm{b}}$ & $66.18^{\mathrm{a}}$ & $18.49^{\mathrm{a}}$ \\
$150 \times 2$ & $5.08^{\mathrm{ab}}$ & $81.41^{\mathrm{a}}$ & $19.89^{\mathrm{a}}$ \\
$175 \times 2$ & $5.11^{\mathrm{ab}}$ & $68.52^{\mathrm{a}}$ & $19.59^{\mathrm{a}}$
\end{tabular}

${ }^{a}$ The same numbers in the same column followed by same word means no significant difference at test degree of 5\% (Duncan multiple range test) 
Table 7. Genetic characteristic of crop height, stem height, stem diameter, segment length, leaves length and leave width of Benggala grass (M1V1)

\begin{tabular}{|c|c|c|c|c|c|c|c|c|}
\hline \multirow{2}{*}{ Characteristic } & \multicolumn{8}{|c|}{ Doses (Gy) } \\
\hline & 200 & 250 & 300 & 350 & $100 \times 2$ & $125 \times 2$ & $150 \times 2$ & $175 \times 2$ \\
\hline \multicolumn{9}{|l|}{ Hight } \\
\hline$\sigma^{2} p$ & 746.60 & 1059.2 & 1338.2 & 928.2 & 1693.1 & 909.5 & 1318.5 & 946.7 \\
\hline$\sigma^{2} g$ & 0.00 & 132.9 & 412.00 & 1.93 & 766.83 & 0.00 & 392.25 & 20.44 \\
\hline $\mathrm{h}^{2}$ & 0.00 & 0.13 & 0.31 & 0.00 & 0.45 & 0.00 & 0.30 & 0.02 \\
\hline $\operatorname{GVC}(\%)$ & 0.00 & 8.03 & 13.02 & 0.95 & 17.22 & 0.00 & 13.82 & 3.40 \\
\hline Criteria of GVC & low & low & low & low & rather low & low & low & low \\
\hline \multicolumn{9}{|l|}{ Stem H. } \\
\hline$\sigma^{2} p$ & 627.83 & 1140.14 & 1090.85 & 812.30 & 1290.51 & 651.54 & 1133.91 & 844.74 \\
\hline$\sigma^{2} \mathrm{~g}$ & 0.00 & 214.28 & 165.00 & 113.5 & 364.66 & 0.00 & 208.06 & 0.00 \\
\hline $\mathrm{h}^{2}$ & 0.00 & 0.19 & 0.15 & 0.14 & 0.28 & 0.00 & 0.18 & 0.00 \\
\hline $\operatorname{GVC}(\%)$ & 0.00 & 17.80 & 17.71 & 0.00 & 24.23 & 0.00 & 17.72 & 0.00 \\
\hline Criteria of GVC & low & rather low & rather low & low & rather low & low & rather low & low \\
\hline \multicolumn{9}{|l|}{ Stem D. } \\
\hline$\sigma^{2} p$ & 0.92 & 0.92 & 1.04 & 0.81 & 1.07 & 0.81 & 0.97 & 1.06 \\
\hline$\sigma^{2} \mathrm{~g}$ & 0.16 & 0.17 & 0.29 & 0.05 & 0.32 & 0.05 & 0.21 & 0.30 \\
\hline $\mathrm{h}^{2}$ & 0.18 & 0.18 & 0.28 & 0.07 & 0.30 & 0.06 & 0.22 & 0.29 \\
\hline $\operatorname{GVC}(\%)$ & 7.84 & 8.35 & 10.38 & 4.44 & 11.06 & 4.69 & 9.09 & 10.72 \\
\hline Criteria of GVC & Low & Low & Low & Low & Low & Low & Low & Low \\
\hline \multicolumn{9}{|l|}{ Segment L. } \\
\hline$\sigma^{2} p$ & 12.34 & 12.74 & 16.05 & 11.80 & 15.24 & 10.35 & 14.57 & 10.52 \\
\hline$\sigma^{2} \mathrm{~g}$ & 1.19 & 1.59 & 4.90 & 0.65 & 4.09 & 0.00 & 3.42 & 0.00 \\
\hline $\mathrm{h}^{2}$ & 0.10 & 0.12 & 0.31 & 0.06 & 0.27 & 0.00 & 0.23 & 0.00 \\
\hline GVC (\%) & 5.67 & 6.59 & 11.59 & 4.21 & 10.57 & 0.00 & 9.30 & 0.00 \\
\hline Criteria of GVC & Low & Low & Low & Low & Low & Low & Low & Low \\
\hline \multicolumn{9}{|l|}{ Leave L. } \\
\hline$\sigma^{2} p$ & 70.68 & 72.36 & 73.02 & 97.14 & 88.44 & 68.80 & 83.84 & 71.94 \\
\hline$\sigma^{2} \mathrm{~g}$ & 19.44 & 21.11 & 21.77 & 45.89 & 37.19 & 17.55 & 32.59 & 20.69 \\
\hline $\mathrm{h}^{2}$ & 0.27 & 0.29 & 0.30 & 0.47 & 0.42 & 0.39 & 0.39 & 0.29 \\
\hline $\operatorname{GVC}(\%)$ & 7.68 & 8.44 & 8.55 & 12.36 & 11.10 & 7.90 & 10.81 & 8.58 \\
\hline Criteria of GVC & Low & Low & Low & Low & Low & Low & Low & Low \\
\hline \multicolumn{9}{|l|}{ Leaves W. } \\
\hline$\sigma^{2} p$ & 0.27 & 0.32 & 0.39 & 0.24 & 0.35 & 0.19 & 0.27 & 0.28 \\
\hline$\sigma^{2} \mathrm{~g}$ & 0.09 & 0.13 & 0.20 & 0.05 & 0.17 & 0.00 & 0.08 & 0.09 \\
\hline$h^{2}$ & 0.31 & 0.42 & 0.52 & 0.21 & 0.47 & 0.01 & 0.31 & 0.32 \\
\hline $\operatorname{GVC}(\%)$ & 14.85 & 17.81 & 24.14 & 11.29 & 20.30 & 2.90 & 15.94 & 14.21 \\
\hline Criteria of GVC & Rather low & Rather low & Rather low & Low & Rather low & Low & Rather low & Rather lov \\
\hline
\end{tabular}

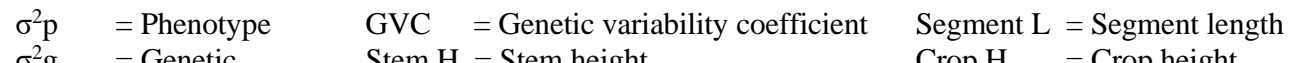

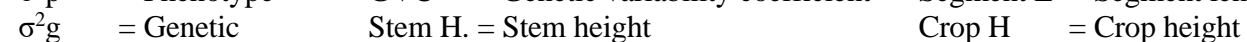

$\mathrm{h}^{2} \quad=$ Heritability Stem D. $=$ Stem diameter

Leaves L. = Leaves length width (Leaves W.) of Benggala grass (M1V1) 
Table 8. Variance of phenotypic $\left(\sigma^{2} \mathrm{p}\right)$, genetic $\left(\sigma^{2} \mathrm{~g}\right)$, heritability $\left(\mathrm{h}^{2}\right)$ and genetic variability coefficient $(\mathrm{GVC})$ of fresh crop weight (Fresh Weight), dry crop weight (Dry Weight) and the number of tiller of M1V1 Benggala

\begin{tabular}{|c|c|c|c|c|c|c|c|c|}
\hline \multirow{2}{*}{ Characteristic } & \multicolumn{8}{|c|}{ Doses (Gy) } \\
\hline & 200 & 250 & 300 & 350 & $100 \times 2$ & $125 \times 2$ & $150 \times 2$ & $175 \times 2$ \\
\hline \multicolumn{9}{|l|}{ Fresh Weight } \\
\hline$\sigma^{2} p$ & 31732 & 45385 & 46423 & 56115 & 68443 & 17636 & 50706 & 34968 \\
\hline$\sigma^{2} \mathrm{~g}$ & 0.00 & 13652 & 12105 & 21797 & 34126 & 0.00 & 16388 & 650.77 \\
\hline $\mathrm{h}^{2}$ & 0.00 & 0.30 & 0.26 & 0.39 & 0.50 & 0.00 & 0.32 & 0.02 \\
\hline GVC (\%) & 0.00 & 33.29 & 35.86 & 47.02 & 56.41 & 0.00 & 40.08 & 10.57 \\
\hline Criteria of GVC & Low & Quite high & Quite high & High & High & Low & Quite high & Low \\
\hline \multicolumn{9}{|l|}{ Dry Weight } \\
\hline$\sigma^{2} p$ & 2027.7 & 2585.5 & 2582.6 & 2913.4 & 3099.2 & 960.45 & 3221.2 & 1835.4 \\
\hline$\sigma^{2} \mathrm{~g}$ & 379.66 & 937.46 & 934.58 & 1265.4 & 1451.2 & 0.00 & 1573.2 & 187.39 \\
\hline $\mathrm{h}^{2}$ & 0.19 & 0.36 & 0.36 & 0.43 & 0.47 & 0.00 & 0.49 & 0.10 \\
\hline GVC (\%) & 25.16 & 35.00 & 39.26 & 42.76 & 47.25 & 0.00 & 45.74 & 20.81 \\
\hline Criteria of GVC & Rather low & Quite high & Quite high & High & High & Low & High & Rather low \\
\hline \multicolumn{9}{|l|}{ The Number of tiller } \\
\hline$\sigma^{2} p$ & 35.68 & 41.30 & 30.43 & 44.91 & 36.68 & 28.04 & 46.81 & 37.55 \\
\hline$\sigma^{2} \mathrm{~g}$ & 16.57 & 22.19 & 11.32 & 25.79 & 17.56 & 8.93 & 27.70 & 18.44 \\
\hline$h^{2}$ & 0.46 & 0.54 & 0.37 & 0.57 & 0.48 & 0.32 & 0.59 & 0.49 \\
\hline $\operatorname{GVC}(\%)(\%)$ & 26.32 & 31.75 & 26.07 & 35.30 & 30.49 & 23.36 & 37.36 & 31.96 \\
\hline Criteria of GVC & Rather low & Quite high & Rather low & Quite high & Quite high & Rather low & Quite high & Quite high \\
\hline $\begin{array}{ll}\Sigma^{2} \mathrm{p} & =\text { Phenotypic } \\
\Sigma^{2} \mathrm{~g} & =\text { Genetic } \\
\mathrm{H}^{2} & =\text { Heritability } \\
\mathrm{GVC} & =\text { Genetic Var }\end{array}$ & 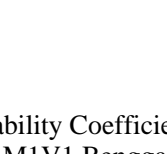 & resh I & resh Cro & Dry W & Dry $\mathrm{Cr}$ & & & \\
\hline
\end{tabular}

Moderate heritability value was at $100 \mathrm{~Gy}$ x 2 and 150 Gy x 2. Heritability and genetic diversity commonly will be linear with genetic diversity coefficient.

\section{CONCLUSION}

The $\mathrm{LD}_{50}$ and $\mathrm{LD}_{20}$ value of Benggala grass cv Purple guinea were 358.23 Gy and 176.83 Gy. This value may be used as a standard in determining gamma ray radiation doses to irradiate the Benggala cv Purple guinea grass. Morphological characteristic of M1 showed that the doses of radiation affected the crop height, leaves width, fresh crop weight and dry crop weight, where the 150 Gy $\times 2$ resulted in the heaviest fresh crop weight. Morphological characteristic of the M1V1 was also influenced by radiation doses, where the heaviest fresh crop weight was at $250 \mathrm{~Gy}$. Moderate to high heritability value was found in the characteristic of the number of tiller, fresh crop weight and dry crop weight; as well the genetic variability had quite high range value which shows a possibility to do selection on those characteristics then it creates Benggala grass which has high production in the acid land.

\section{REFERENCES}

Abdullah TL, Endan J, Nazir BM. 2009. Changes in flower development, chlorophyll mutation and alteration in plant morphology of Curcuma alismatifolia by gamma irradiation. Am J App Sci. 6:1436-1439.

Aganga AA, Tshwenyane S. 2004. Potentials of Guinea grass (Panicum maximum) as forage crop in livestock production. Pak J Nutr. 3:1-4.

Aisyah SI, Aswidinnoor H, Saefuddin A, Marwoto B, Sastrosumarjo S. 2009. Induksi mutasi pada setek pucuk anyelir (Dianthus caryophyllus Linn.) melalui iradiasi sinar gamma. J Agron Indonesia. 37:62-70. 
Akashi R, Adachi T. 1991. High frequency somatic embryo formation in culture on immature embryo of guinea grass (Panicum maximum Jacq). Jap J Breed. 41:85-93.

Almeida AAS, Monteiro FA, Jank L. 2000. Avaliação de Panicum maximum jacq. para tolerância ao alumínio em solução nutritiva. R Bras Ci Solo. 24:339-344.

Ambavane AR, Sawardekar SV, Sawantdesai SA, Gokhale NB. 2015. Studies on mutagenic effectiveness and efficiency of gamma rays and its effect on quantitative traits in finger millet (Eleusine coracana L. Gaertn). J Radiation Res App Sci. 8:120-125.

Bermawie N, Wahyuni S, Heryanto R, Setiyono RT, Udarno L. 2013. Observasi hasil dan mutu lada lokal di dua agroekologi. Buletin Littro. 24:64-72.

Carnevalli RA, Silva SC da, Bueno AAO, Uebele MC, Bueno FO, Hodgson J, Silva GN, Morais JPG. 2006. Herbage production and grazing losses in Panicum maximum cv. Mombaça under four grazing managements. Trop Grassl. 40:165-176.

Chen CP, Hutton EM. 1992. Panicum maximum Jacq. In: Mannetje L.'t, Jones RM, editors. Plant Resources of South-East Asia No. 4: Forages. Wageningen (Netherlands): Pudoc Scientific Publisher. p. 172-174.

Giono BRW, Farid BDR, Nur A, Solle MS, Idrus I. 2014. Ketahanan genotipe kedelai terhadap kekeringan dan kemasaman, hasil induksi mutasi dengan sinar gamma. J Agroteknos. 4:44-52.

Hanafiah DS, Trikoesoemaningtyas, Yahya S, Wirnas D. 2010. Studi radiosensitivitas kedelai [Glycine Max (L) Merr] varietas argomulyo melalui irradiasi sinar gamma. Bionatura-J Ilmu-ilmu Hayati dan Fisik. 12:103-109.

Hanafiah DS. 2012. Perbaikan karakter agronomi dan adaptasi terhadap cekaman kekeringan pada kedelai [Glycine $\max$ (L.) Merr.] melalui iradiasi sinar gamma dosis rendah (Disertasi). [Bogor (Indones)]: Institut Pertanian Bogor.

Hare MD, Tatsapong P, Phengphet S. 2009. Herbage yield and quality of Brachiaria cultivars, Paspalum atratum and Panicum maximum in north-east Thailand. Trop Grassl. 43:65-72.

Kalton RR, Smit AG, Leffel RC. 1952. Breeding perennial forage grasses. In: Hanson AA, Carnahan HL, editors. Technical Bulletin 1145. United States Department ff Agriculture.

Karti PDMH. 2016. Strategi pengembangan tanaman pakan pada lahan marjinal untuk ketahanan pakan nasional. Makalah Orasi Ilmiah Guru Besar IPB. [Bogor (Indones)]: Institut Pertanian Bogor.
Lubis K, Sutjahjo SH, Syukur M, Trikoesoemaningtyas. 2014. Pendugaan parameter genetik dan seleksi karakter morfofisiologi galur jagung introduksi di lingkungan tanah masam. Penelitian Pertanian Tanaman Pangan. $33: 122-128$

Moedjiono, Mejaya MJ. 1994. Variabilitas genetik beberapa karakter plasma nutfah jagung koleksi Balittan Malang. Zuriat. 5:27-32.

Nakamanee G, Srisomporn W, Phengsavanh P, Samson J, Stür W. 2008. Sale of fresh forage a new cash crop for smallholder farmers in Yasothon, Thailand. Trop Grassl. 42:65-74.

Nur A, Human S, Trikosoemaningtyas. 2014. Keragaman Genetik Gandum Populasi Mutan M3 di Agroekosistem Tropis. J Ilmiah Aplikasi Isotop dan Radiasi 10:35-44.

Poerba YS. 2004. Penampilan genotipe som Jawa (Talinumpaniculatum Jacq. (Gaertn.)) pada generasi M2. Berita Biologi. 7:127-134.

Pongtongkam P, Nilratnisakorn S, Piyachoknakul S, Thongpan A, Aranananth J, Kowitwanich K, Tadsri S. 2005. Inducing salt tolerance in purple Guinea grass (Panicum maximum TD58) via gamma irradiation and tissue culture. Kasetsaart J Nat Sci. 39:681-688.

Ratsamee S, Akaracharanya A, Leepipatpiboon N, Srinorakutara T, Kitpreechavanich V, Tolieng V. 2012 Purple Guinea grass: Pretreatment and ethanol fermentation. Bio Resources. 7:1891-1906.

Satoto, Suprihatno B. 1996. Keragaman genetik, heritabilitas, dan kemajuan genetik beberapa sifat kuantitatif galurgalur padi sawah. Penelitian Pertanian Tanaman Pangan. 15:5-9.

Setiawan RB, Khumaida N, Dinarti D. 2015. Induksi mutasi kalus embriogenik gandum (Triticum aestivum L.) melalui iradiasi sinar gamma untuk toleransi suhu tinggi. J Agron Indonesia. 43:36-44.

Seyoum M, Alamerew S, Bantte K 2012. 'Genetic variability, heritability, correlation coefficient, and path analysis for yiels and yield related traits in upland rice (Oryza sativa L.). J Plant Sci. 7:13-22.

Singh RK, Chaundhary BD. 1977. Biometrical methods in quantitative genetics analysis. New Delhi (India): Kalyani Publishers.

Sobrizal 2016. Potensi pemuliaan mutasi untuk perbaikan varietas padi lokal Indonesia. J Ilmiah Aplikasi Isotop dan Radiasi. 12:23-35.

Sudrajat DJ, Zanzibar M. 2009. Prospek teknologi radiasi sinar gamma dalam peningkatan mutu benih tanaman hutan. Info Benih. 13:158-163. 